\title{
No Dope: Try to Cope
}

Thomas Mann

66 What the hell is a guy supposed to do but sell and use dope?" I repeatedly asked myself. I had just been transferred to Pittsburgh Institution (P.I.), a sleepy farm camp just outside of Kingston, Ontario. I was six months into a seven year sentence for "Conspiracy to Traffic." I had lucked out and grabbed camp, right off the hop, so had zero to complain about. However, this camp seemed "different." Eighty percent of the guys did not seem to be crooks, but looked like they should be in psychiatric or geriatric wards. Many creepy looking old guys, who I later would come to know were creepy old guys, young punks and an odd mix of yuppie looking "inmates". I had not been in many joints, but this place seemed mighty odd.

P.I. was a huge contrast to Millhaven Reception, the Maximum Security Assessment Unit, where I had just been. My hometown was more than well represented at Millhaven, making me wonder whether it was keen cops, or dumb crooks that brought us all together. Life was no hell, but there were no wrongfully convicted -Guy Paul Morins-amongst us, so we all just did our thing. We kept stoned, shared our war stories, and schemed about future scams; never once thinking our lives would change significantly, now or ever.

Since "the get go," I just assumed from Millhaven I would go to Collin's Bay or Joyceville, both medium security prisons. In both places I had friends and potential sources for dope. For twenty years as a dope dealer, I was always part of a crew. There were partners, customers and women: always a party, always somebody around. This was the first time in memory I was totally on my own and did not know a soul. There was no shortage of guys selling dope, but not one who did not look "shaky" to me. I did not trust anyone, so I kept to myself. After a couple of days, my stash was empty and hello reality. Out of default, I was sober for the first time in decades. It was not fun.

A number of times during the next few weeks I thought I was "bugging out." I was irritable, restless and could not sleep. Night after night I stared up at the cobwebs and crud on the ceiling in P.I.'s dormitory. Reminiscing about the years of coke, booze and always, always smoke. By day I wandered around like a zombie, just going through the motions. I had absolutely no patience for anything. Eventually my mail began filling up the cardboard box under my desk "my luggage" from Millhaven. I was so restless, I had not responded to 
anyone's correspondence for ages. One day, out of boredom, I wrote up a list of everyone I needed to write, and slowly began kicking out the mail.

Anyone, anywhere, who I knew, or frankly some folks I did not know, got a letter. If I received a letter from someone, their name would go up on the list, and they would get a response within days. My thirst for good "bud," was replaced by neurotic letter writing. Every waking moment, day or night, I hammered out mail at the rate of 10 or 15 letters a day. I described my surroundings, made heartfelt explanations or speculations to relatives, tried to serenade the odd ex-girlfriend, and even wrote a poem or two. In hindsight I was being obsessive as hell, but out of the madness a spark was ignited.

A few months passed, and one day in a canteen lineup, I overheard a familiar name: Rosie Rowbotham. Not that I had ever met the guy, but he was infamous inside and out. For years, I had heard stories of Toronto's Rochdale College, where every exotic type of dope could be found. Word far and wide was that Rosie Rowbotham ran the show. He also was a former client of my lawyer, so I had often heard tales of woe about Rosie's many legal exploits. In hindsight, I was also learning firsthand about clientlsolicitor privilege, or lack thereof.

Rosie and I got to know each other when he was working with his old smuggling partner Richard Stratton, on an innovative publication out of New York, called PrisonLife Magazine. At one point he asked if I would help out with an article. "What did I know about prisoners, much less magazines," I responded? Rosie threw it back at me simply, and to the point, "It doesn't matter what you know now, use your savvy to find out the answers. Talk to the old cons and more importantly listen to them."

After a long pause, I asked about style and structure, etiquette and design. Rosie again lobbed all my misgivings and hesitations back at me, "There's three types of writing: news, features, and editorial. You start with the news pieces and progress from there. Keep it short, simple and to the point. Not boring, but no bullshit. The deadline is such and such ... go to it."

I was horrified to a degree, but what the hell, it was something to do, and Lord knows I had the time. I circled around the story a hundred times, but eventually got it down and off to New York it went. Weeks later the new PrisonLife Magazine, arrived, complete with the new 
"Canadian Scene" page. It was quite thrilling to be published, not to mentioned being threatened by the Correctional Service of Canada staff over the content, but this story now signifies much more to me. That is where I started.

Before long, three or four hours of everyday were spent at my computer. It was an old " 386 ," that crashed more than it computed, but it did the job. Luckily the computer hacks knew enough tricks and could scrounge enough parts, to keep me writing. PrisonLife Magazine articles, letters to newspaper editors, personal letters galore; and I even started taking University courses and started knocking out essays. Days and months began whipping by, and rarely did I ever think about getting high.

The next wave came with PrisonLife Television - a weekly one hour Cablenet television show exploring crime and punishment issues, hosted by Rosie. Of course my case workers would not let me be part of the convict crew who attended on passes from minimum security prisons, but Rosie kept me busy nevertheless. The mainstream media seemed to get a kick out of $P L T V$, so there were no shortage of queries. More challenges for my shaky 386 answering mail, writing potential guests and interacting with various journalists.

My folks were all about community service and causes, but my only mission in life had been a buck or a buzz Now things were different.

I had never done hard-time, but my life had quickly become inundated with men and women who had been a part of the system most of their lives. Brothers and sisters, parents, children, aunts - uncles, yet prisoners. Different names, but for far too many their stories tragically similar. Tough family backgrounds, if any family life at all; poverty, self-esteem issues, and too often histories of abuse. Instead of homes; orphanages, training schools, young offenders facilities, provincial joints, and ultimately graduation to the federal system. Many never had a chance, ever. This made my prisoner media projects not simply a way to do time, but a significant endeavour.

My view of the prison system had changed radically from the inside - out. It became clear that culturally and historically we had been locking people up for centuries, because that is what we have always done. Government experts and countless studies knew what problems needed to be addressed within communities, but for them its not 
politically palatable to seek results versus punishment. Often the argument was money, but it was clear billions of dollars were being spent on policing and imprisonment rather than addressing the truth. Systematic abuse was creating a commodity, labeling the group criminals, to be used as fodder for a massive, brutal, and unforgiving machine: the prison system.

My disgust for the prison reality was a stimulus for me to advocate, which meant to write. In turn, I became so busy that time began to whiz by and I was "honing in" on a potential parole. "What the hell was I going to do for work?" I began asking myself. I had never really considered a new career. I had a fairly successful one for decades, but the downside was obvious. I had played around a wee bit with a few construction related jobs, some more successful than others, but my real career was drugs. I liked the challenges, the teamwork, the adventure, and the rush. I got off on beating the odds.

Spurred on by PrisonLife Magazine and Television projects, I began to ponder a career as a story-teller: a journalist. I suspected it might be rewarding both financially and personally, and there most likely would be no shortage of challenges. However, I was a little shy about entering "the straight" workforce labeled a parolee, or ex-con.

I pondered how my past may be a deterrent? How would it affect my lengthy parole? Was I too burnt after years "on the wildside?" One prisoner, who was a professional writer and film-maker, just scowled saying "Writers write, talkers talk. What are you doing?" He infuriated me, but in hindsight was a good motivator. Many prisoners around PI laughed at the idea. Dismissed me as a dreamer. My parents, whom I had become reacquainted with while inside shuddered at the thought. In hindsight, all likely just dismissed my murmuring as a front for selling dope. I could not blame them.

In contrast, there was one person who saw things quite differently: Rosie. He angrily told me

You never ratted on anyone, or forced anyone to buy your stuff. You've absolutely nothing to be ashamed of. Get out there and tell the mainstream the way its is. Its not doing anyone any favours. It'd be helping people inside and out to know the truth. To share some insight. Richard and Kim 
(Stratton) are doing it in the States, and making a difference.

There's lots of work for us here in Canada.

Instead of listening to anyone else, I chose to hear my buddy. After a couple of years at P.I., I received the green light, loaded up my old "386," and headed to a halfway house.

Working on the weekends in a restaurant washing dishes was not part of my dream. It seemed a little surreal frankly, and quite a contrast to my previous lifestyle. At least it was giving me the time to write during the week, and to travel down to Kingston on Monday nights to work on PrisonLife TV. I was not having any great success selling any of my writing, but was keeping busy with pro bono newsletter pieces and PrisonLife Magazine. Kim and Richard in New York were patient editors and it sure was rewarding to play a small part in their work.

After writing a memorial piece about prison activist Claire Culhane, a story which has impacted me personally and professionally in many significant ways, I was horrified with the closure of PrisonLife Magazine. It was for all the right reasons, but a shock. Next PrisonLife Television, got the axe. Six months out, both trump cards gone. Keep washing those dishes!

Seven months later, I got out of the halfway house and moved into my own little apartment. It was out in the country in a ramshackle old house. My landlord hated the system and had no trouble housing a convict, but also hated furnaces, which we lacked. He let me pay my rent by doing renovations and I got a part-time job at a ski hill. By night I fired up the computer (now a laptop), that is, when its LCD screen was not frozen solid, because of lack of heat.

About this time, I heard a radio interview with a fellow named Harry Wu. He had done 19 years in a Chinese slave labour camp for speaking out for democracy. It totally fascinated me that he had suffered so much for his thoughts and beliefs. Through the internet I discovered an address for his organization and I wrote him a long letter. He was someone I just had to meet and interview. Much to my surprise, a few months later the phone rang and a quiet voice said "Hi it's Harry. What can I do for you?" I was floored. We discussed the possibility of an interview, but I certainly could not travel to the US. We concluded the call with the agreement he would be in touch when he was nearby and 
possibly could fly into Ottawa. I had no idea what this would ultimately mean.

Months passed, and I was still writing daily, with little success. Rosie and a vast chorus of ex-prisoners and prisoner advocates pitched in on a number of projects, helping me along the way. This is when I first became acquainted with The Journal for Prisoners on Prisons, and Donald Marshall Jr. graciously agreed to an interview. ${ }^{1}$ During this interview, "Junior" asked me about adjustment? It made me question my situation for the first time. I was a relative hermit, living in a new city, but in a bubble. I did not allow anyone into my life unless they were excons or sympathetic "to the cause". I had become very introverted and suspicious, bordering on paranoia. In retrospect, it was not too healthy.

After literally dozens of unsold stories, I rejoiced when I sold my first mainstream press feature. I celebrated the paltry cheque, then anguished over the ensuing consequent lawsuit. The high priced newspaper lawyer told me "the truth is immaterial". It was cheaper for them to settle out of court. I was fed to the wolves and treated like dirt. Convict prejudice? Who knows? But it was not great for my confidence. Next came a job layoff, then a couple police setups, funerals ... on and on and on. Not a high point in the career, but the laptop carried on!

A number of cold months later, I began working part-time in a shelter for homeless men. During the first shift, a gritty HIV positive alcoholic went into a grand mal seizure. I will never forget the incident, and luckily "Wobbles" recovered. Within a few weeks, fights, seizures, suicide attempts and funerals blurred together with the commonplace. There was so much tragedy and suffering there just never was enough time or energy. Most of the staff were stressed out and very bitter. Predominantly aspiring law enforcement types, trying "to pad" their resumes to get the big job and get out there and control. It was all quite insane, but the people real. A perfect place for me.

One day I was interviewed in the local paper about Prisoners' Justice Day, and things drastically changed for me at the shelter. Much of the staff were horrified to be working with "a convict," but no one said a word to my face. Immediately management started playing games trying to torment me into quitting. The saving grace was being a writer. Management feared that I may write a story sharing my observations on their operations. On the other hand, the clients were thrilled. There are not many residents of homeless shelters who have not been in one 
institution or another over the years. Most had not fallen through the cracks in the social web, they were born in the cracks. Regularly someone I had met inside would walk through the door of the shelter freshly out of the joint. Before long it became evident in most ways that I had far more in common with the residents than the staff. Many became good friends. Sadly I have buried too many since.

Months later I received a call from the leader of China Democracy Ottawa. He said he had been given my name by Harry Wu, and they needed some help. Harry was planning to visit Ottawa in chorus with a visit to Canada of the President of The People's Republic of China. The goal was to underscore to the press that no human rights atrocities in China were being overlooked in lieu of lucrative trade deals. I admitted I knew little about China, and less about its human rights abuses, but sure I would try to help.

After months of preparation, Harry arrived and we were greeted enthusiastically by all the principals of the Canadian print and electronic media. A highlight was an interview between Harry and Rosie, for $C B C$ National Radio, which was a huge hit. After an exhausting three days of demonstrations, meetings, interviews, and a presentation to the Federal Justice and Human Rights Committee, our efforts were deemed a tremendous success. Harry asked if I would drive him to the airport at the conclusion of his trip, and it was a remarkable moment. He asked many questions about my past and his final words were, "Your on the right path, but you're still healing. It's obvious soon you'll be able to accomplish all your goals. Just be patient."

The notion of healing irritated and baffled me for a time. It shocked me that anything like this would be so apparent to a stranger. In hindsight, Harry was right. I was still coping with trying to change my life, adapt, find a place to fit in. All my adult life had been dominated by drugs, scams, and ultimately the criminal justice system. In ways I felt ancient and in other ways infantile. I questioned what I had missed during the ages 13 through 34 , when I was totally buzzed out and preoccupied? My sense of happiness had always been making a big chunk of cash, or a big party, waking up with the good looking dancer.

I manifested a lot of guilt and anger. Prison had confirmed the hypocrisy of our system. The experience created more questions than answers. However, the one redeeming quality was that I was writing myself "out of the mire." I was developing a new career, and it was also 
helping me to make some sense out of "the straight world," I knew so little about.

A few months later, in a positive gesture to the western world, prior to the OPEC summit in Vancouver, Chinese dissident Wei Jingsheng was released from a torturous incarceration in China. Again I was approached by local Chinese human rights advocates to help organize the visit and to lobby the Canadian Government and public by exposing China's violations. After that other groups and organizations inquired if I would help them with their press and promotions. There was never any pay, but I enjoyed the challenges, action and surprises. Not quite the rush of a border, but close.

I have frequently been asked to speak about prison, crime and drug use at social groups, schools and universities. One day I received a phone call from a teacher in Mississauga, and after a lengthy chat, she asked me if I would come to speak to her class about China. It was a significant event for me. I was not abandoning my past, but taking a small step in a different direction: a different identity. It was quite empowering. I was developing self-confidence and spending less time and energy looking over my shoulder. I began to realize there were many in the community who shared my cynicism concerning government. Very slowly I was coming to realize that it was not a blanket us and them in society. I became aware that I did not have prisoner/criminal tattooed on my forehead, and there were many who would not have cared if I did. This was an important coming of age issue for me. I was beginning to let it go. I had been a pirate for years, and it was taking years for me to evolve, but it slowly was beginning to happen. Harry had been right.

A little more than two years later, with some regrets I resigned from the shelter. Not to turn my back, but I know I can do so much more for the homeless and incarcerated on a macro-level, through the mass media, working within organizations, and by government lobbying. I am now a professional writer, broadcaster and video producer. Regularly I do both advocacy and media work with Rosie, which is always a pleasure. There is no shortage of ups and downs but it would be boring otherwise. However, if it was not for so, so many inside and out who have suffered so immensely, I would not have a career.

To these scores of men and women, my desire is to always speak out and try to inspire positive change. In this I know there is a lot more for me to do, but use and sell dope. 


\section{ENDNOTES}

1 Donald Marshall Jr., Guy-Paul Morin and David Milgaard were all wrongly convicted for homicides in Canada, and have since been exonerated by the Courts. 
During the most vibrant years of the Canadian penal press, magazines like the Kingston Penitentiary Telescope (1950-68) and the Ste. Vincent de Paul Penitentiary Pen-O-Rama (1951-68) were fêted by prison administrators and senior management as exemplifying the new spirit of penal reform and its attendant rehabilitative regime. The Canadian penal press served as an adjunct to the trades/training programs that were the pride and focus of the prison reform movement. The penal press publicized the new reformative/vocational programs and in doing so exemplified their success. When the penal reform initiative began to wane in the 1960 s, prisoners used the penal press to fight for continued change and liberalization. At this point official support was withdrawn and prisoner's commentary was redefined as "incessant bitching". This signalled the demise of the nine "original" penal press magazines in Canada (Gaucher,1989).

How does one write about carceral life without addressing its grim everyday realities? In the quest to reveal the "truths" hidden behind prison walls, the JPP also lays itself open to charges of "incessant bitching". The academic format and focus of the journal exacerbates this situation by directing prisoners to analyse the prison. However, the convict's adjustment to prison realities has traditionally produced a wry philosophical perspective, characterized by Harvey Blackstock (1967) as Bitter Humour. In coping with the depressing blackness and overwhelming futility of carceral life, prisoners assert their spirit by "taking up" their collective predicament. Frank Norman's (1958) Bang to Rights is another classic in this well establish prison writing tradition. This self-protective "bitter humour" also provides penetrating insights into the daily encounters and routines of life in a total institution. Indeed, throughout the history of the Canadian penal press, it has been this style of writing that most infuriated prison censors. This type of article has been most evident in the Canadian penal press just prior to serious struggles over censorship and content, and often, the demise of the magazine in question.

In this our $10^{\text {th }}$ anniversary issue we would like to feature this prison writing style. Seth Ferranti, a new recruit, portrays the "awakening" that often accompanies criminalization, while Gerald Niles presents us with a travelogue of his extensive "Tour" of prison facilities. Greg McMaster provides a considered examination of that penal fetish, "the hole". While the seriousness of their topics are obvious, these 
bittersweet takes on them exemplify the spirit of resistance that is characteristic of much prison writing.

\section{REFERENCES}

Blackstock, H. 1958, Bitter Humour, Toronto: Burns \& MacEachern.

Gaucher, B. 1989, "The Canadian Penal Press: A Documentation and Analysis" Journal of Prisoners on Prisons, vol 2:1; 3-24.

Norman, F. 1958, Bang To Rights, London: Martin Secker \& Warburg Ltd. 